\title{
Astragaloside IV promotes cardiac remodeling after myocardial infarction by inhibiting DNMT3B-mediated Runx3 methylation via downregulating LncRNA MIRT1 expression
}

\author{
Jing $\mathrm{GAO}^{1 *}$, Chunming MENG ${ }^{1 *}$, Li GUAN ${ }^{1}$, Hong $\mathrm{ZHANG}^{2}$, Wei ZHANG ${ }^{3 *}$ (D)
}

\begin{abstract}
Astragaloside IV (AS-IV) has been shown to possess cardioprotective effect. However, the specific mechanism of AS-IV in myocardial infarction (MI) remains unclear. Our results showed that AS-IV intervention observably enhanced cell viability and reduced cell apoptosis, oxidative stress levels and inflammatory factor secretion. Expression of MIRT1 was significantly up-regulated in hypoxia-treated cells. In addition, ALCAM overexpression reversed the effects of AS-IV intervention on hypoxia-treated cell functions. MIRT1 facilitated Runx3 promoter methylation and its downregulated expression by recruiting DNA methyltransferase 3B (DNMT3B) to the Runx3 promoter region through binding with suppressor of Zeste 12 protein homolog (Suz12). Runx3 silencing reversed the effects of MIRT1 inhibition on hypoxia-treated cell functions. Betulinic acid suppressed the effects of AS-IV intervention on the behaviors of hypoxia-treated cells. AS-IV treatment improved the cardiac functions of mice with MI. Taken together, these findings demonstrated that AS-IV treatment inhibits DNMT3B-mediated Runx3 promoter methylation by restraining Suz12 expression and further blocks the NF- $\mathrm{kB}$ signaling pathway, and in turn improves the cardiac functions of mice with MI.
\end{abstract}

Keywords: myocardial infarction; Astragaloside IV; Suz12; DNMT3B; Runx3; NF-кB signaling pathway.

Practical Application: Astragaloside IV may be developed as a main component of an effective drug for treating myocardial infarction.

\section{Introduction}

Myocardial infarction (MI) is one of the leading causes of morbidity and mortality worldwide (Lu et al., 2015). It is usually caused by coronary artery obstruction, leading to chest pain, weakness, sweating, dyspnea, palpitations and even unconsciousness (Boateng \& Sanborn, 2013). With the development of treatment methods, the incidence of $\mathrm{MI}$ is decreasing in most countries. However, the burden of MI has generally increased due to the aging of the world population, population growth, and rising prevalence of long-term survivors of MI (Pollard, 2000). The treatment of this disease requires further in-depth study of novel therapeutic drugs.

Astragaloside IV (AS-IV) is a traditional Chinese medicine isolated from Astragalus Linn membranaceus (Li et al., 2017a). AS-IV has potent anti-inflammatory, anti-fibrotic, anti-oxidative stress, anti-asthma, anti-diabetes and immunomodulatory effects, and has a variety of pharmacological effects (Zhang et al., 2020). In addition, AS-IV has been shown to exert anti-tumorigenic properties in certain cancers, such as lung cancer, breast cancer and colorectal cancer (Chen et al., 2018; Xu et al., 2018; Zheng et al., 2019). AS-IV has been reported to have a protective effect on the heart and enhance angiogenesis and cardiac remodeling after MI (Cheng et al., 2019). AS-IV promotes angiogenesis through vascular endothelial growth factor and basic fibroblast growth factor in mice with myocardial infarction (Yu et al., 2015). In addition, AS-IV enhanced the cardioprotective effect of remote ischemic conditioning on MI induced heart failure and ventricular remodeling and was considered as a potential therapeutic agent to preserve cardiac function and improve MI prognosis (Cheng et al., 2016). However, the underlying mechanism through which AS-IV exerts cardioprotective effects remains unclear.

Increasing evidence suggests that long noncoding RNAs (lncRNAs) play an important role in the regulation of physical and pathological processes in many organisms, including the cardiovascular system. For example, inhibition of lncRNA ANRIL relieved myocardial cell apoptosis and improved heart function in AMI mice (Yang et al., 2019). LncRNA-MALAT1 up-regulated the expression of BECN1 by binding to miR-30a, thereby increasing the level of cell autophagy after MI (Zhang \& $\mathrm{He}, 2020$ ). LncRNA MIRT1, first discovered by Zangrando et al., was significantly upregulated during AMI (Zangrando et al., 2014). Downregulation of MIRT1 ameliorated myocardial I/R injury in aged diabetic rats by attenuating cardiac function damage, and reducing myocardial fibrosis area, as well as reducing myocardial apoptosis, oxidative stress, and inflammatory damage (Liu et al., 2019). However, the role of MIRT1 in AMI remains unclear. 
Runt-related transcription factor (RUNX) family transcription factor is components of the TGF-b signaling pathway and can regulate cell functions, such as cycle regulation, differentiation and apoptosis, and malignant transformation (Chen et al., 2010). Runx 3 has been identified as a candidate tumor suppressor gene in a variety of human tumors (Lotem et al., 2015; Zhou et al., 2017). In addition to its role in malignant tumors, Runx 3 is also involved in the immune system and inflammatory pathways (Lotem et al., 2017). In addition, methylation-dependent transcriptional inhibition of Runx3 regulates the viability of cardiovascular endothelial cells in mice after myocardial infarction (Wang et al., 2019). Based on the above reports, we hypothesized that Runx3 may be related to the progression of MI.

Based on the above reports, the present study attempted to explore the underlying regulatory mechanism of AS-IV and MIRT1 on the progression of MI in vitro and in vivo, contributing to the development of MI treatment.

\section{Materials and methods}

\subsection{Animals and experimental groups}

Fifty C57BL/6 male mice (8-12 weeks old, weighing 20-25 g) were provided by experimental animal center of Nanjing Medical University (Nanjing, China). Mice were housed in separate cages with free access to food and drinks under alternating $12 \mathrm{~h}$ light/dark cycles at a controlled room temperature of $25^{\circ} \mathrm{C}$. After 7 days of adaptive feeding, 0.4-0.5 ml/100 g 1\% sodium pentobarbital was injected intraperitoneally into 38 mice. MI was induced in mice by ligating the left anterior descending coronary artery. These mice were designated as MI mouse models. The remaining 12 mice underwent sham treatment and the same surgical procedures as AMI mice, except that they did not receive ligation of the left anterior descending coronary artery. Of these, 36 successfully modeled MI mice were used for comparison with mice receiving control sham surgery.

Mice in the four groups (each, $\mathrm{n}=12$ ) were randomly selected prior to surgery. 36 Mice that survived $>48 \mathrm{~h}$ following surgery were randomly divided into an MI group, a $20 \mathrm{mg} / \mathrm{Kg}$ AS-IV (dissolved in 1\% DMSO; high performance liquid chromatography > 98\%; Shanghai Baoman Biotechnology Co., Ltd., Shanghai, China) treatment group and a $40 \mathrm{mg} / \mathrm{Kg}$ AS-IV treatment group (each, $\mathrm{n}=12$ ) $48 \mathrm{~h}$ following surgery. AS-IV treatment groups were administered at $48 \mathrm{~h}$ after surgery, and the MI model group received the same volume of saline as the $20 \mathrm{mg} / \mathrm{kg}$ AS-IV group. Following 4 weeks, anesthesia was administered to all mice via an intraperitoneal injection of $50 \mathrm{mg} / \mathrm{Kg}$ sodium for $30 \mathrm{~min}$. mice were then sacrificed via carotid arterial exsanguination. The heart apex was collected for histological analysis, RT-qPCR analysis and western blot analysis.

This research study was conducted with the approval of the ethics committee of The First Affiliated Hospital of Kangda College of Nanjing Medical University (Lianyungang, China). Animal experiment procedures were performed in strict accordance of protocols approved by the Institutional Animal Care and Use Committee.

\subsection{Cell culture and treatment}

Mice cardiomyocytes (HL-1) were obtained from American Type Culture Collection (ATCC, Manassas, VA). The cells were maintained in Dulbecco's Modified Eagle Medium (DMEM) (Gibco, Rockville, MD) supplemented with $10 \%$ fetal bovine serum (FBS) (HyClone, Salt Lake City, UT) and 1\% penicillin-streptomycin (Sigma, St. Louis, MO, USA) at $37^{\circ} \mathrm{C}$ in a controlled humidified atmosphere with $5 \% \mathrm{CO}_{2} .2 \times 10^{5}$ cells were plated in 6-well plates and incubated. The culture medium was replaced once every 2 days, and the cells were passaged by $1 \%$ trypsin when they reached $80 \% \sim 90 \%$ confluence. The experimental cells were divided into 2 groups, the control group and the hypoxia group. For the control group, cells were maintained at $37^{\circ} \mathrm{C}$ in $5 \% \mathrm{CO}_{2}$ and $20 \% \mathrm{O}_{2}$. For the hypoxia group, cells were exposed to hypoxia $\left(2 \% \mathrm{O}_{2}\right)$ for $24 \mathrm{~h}$. DNMT3B inhibitor SGI-1027 $(7.5 \mu \mathrm{M})$ and the NF- $\kappa B$ pathway inhibitor betulinic acid $(10 \mu \mathrm{M})$ were purchased from Sigma (St. Louis, MO, USA). AS-IV was dissolved in DMSO and made up with the medium. AS-IV with concentrations of 10 and $50 \mu \mathrm{g} / \mathrm{ml}$ were used to treat cells.

\subsection{Cell transfection}

The siRNA against MIRT1 and Runx3 and the corresponding negative controls were bought from Sangon (Shanghai, China). Full-length cDNA coding sequence of MIRT1 was inserted into the pcDNA3.1 empty vector. Before transfection, HL-1 cells were digested by using $1 \%$ trypsin treatment. After being counted in a blood counting chamber, the cells were plated onto six-well culture plates for $24 \mathrm{~h}$ and then transfected at 40\%-60\% confluence. All transfection was performed by using Lipofectamine 3000 (Thermo, Waltham, MA, USA) according to manufacturer's instructions.

\subsection{RNA extraction and RT-qPCR}

Total RNA from cultured cells and tissues was extracted by using Trizol reagent (Invitrogen, Carlsbad, CA, USA) with the manufacturer's instructions. Reverse transcription was carried out by using Prime Script RT reagent Kit (Takara, Dalian, China). Real-time PCR analyses were conducted with the SYBR Premix Ex Taq II (Takara, Dalian, China) on an ABI 7500 Real-Time PCR System (Applied Biosystems, Foster City, CA) under the following conditions: $95^{\circ} \mathrm{C}$ for $1 \mathrm{~min}$, and then $95^{\circ} \mathrm{C}$ for $20 \mathrm{~s}$, $56^{\circ} \mathrm{C}$ for $10 \mathrm{~s}$ and $72^{\circ} \mathrm{C}$ for $15 \mathrm{~s}$ for 35 cycles. The PCR conditions are as follows: $2 \mu \mathrm{L}$ of cDNA was added to $10 \mu \mathrm{L}$ of the $2 \times$ SYBR green PCR master mix with $0.4 \mu \mathrm{L}$ of Taq polymerase enzyme (RiboBio Co., Ltd, Guangzhou, China), $0.8 \mu \mathrm{L}$ of each primer and $6 \mu \mathrm{L}$ of ddH2O to a final volume of $20 \mu \mathrm{L}$. The relative expression was normalized to glyceraldehyde 3-phosphate dehydrogenase (GAPDH) and calculated by the $2^{-\triangle \Delta C T}$ method. The primer sequences were as follows: MIRT1 forward, 5'-CTT GTT GTC TAA GTG AGT A-3'; and reverse, 5'-TTA ATC GTT CCT CTA GTT G-3'; Suz12 forward, 5'-TGC TTG AGC CCA GTA AGT CG-3'; and reverse, 5'-GGT CTT ACG CTC CGG AGA TG-3'; GAPDH forward, 5'-TGA CCA CAG TCC ATG CCA TCA C-3'; reverse: 5'-GCC TGC TTC ACC ACC 
TTC TTG A-3'. The relative expression levels were calculated by using $2^{-\Delta \Delta C T}$ method.

\subsection{Cell viability assay}

The Cell Counting Kit-8 (CCK-8) assay was performed to detect cell viability. The cells were seeded in 96-well plates. After $48 \mathrm{~h}$ of transfection, a total of $10 \mu \mathrm{L}$ of CCK-8 solution was added into each well and incubated for $2 \mathrm{~h}$ at $37^{\circ} \mathrm{C}$ with $5 \%$ $\mathrm{CO}_{2}$. The absorbance at $450 \mathrm{~nm}$ wavelength was measured by an automatic microplate reader (Bio-Rad, Hercules, CA, USA).

\subsection{Western blotting}

The cells were washed twice with ice-cold PBS and lysed by using RIPA lysis buffer (CW Biotech, Beijing, China) supplemented with protease inhibitor (Roche Diagnostics, Basel, Switzerland). Then the protein concentration was measured by BCA protein assay kit (Thermo Fisher Scientific, Waltham, MA, USA). Equal amount of protein was subjected to $10 \%$ SDS-PAGE at $70 \mathrm{~V}$ for $30 \mathrm{~min}$ then $120 \mathrm{~V}$ for $90 \mathrm{~min}$. And the protein bands were transferred to PVDF membranes at $300 \mathrm{~mA}$ for $2 \mathrm{~h}$. The membranes were blocked with 5\% skim milk for $2 \mathrm{~h}$ at room temperature, and then incubated with the following primary antibodies: rabbit polyclonal GAPDH antibody (1:2500, Abcam, ab9485), rabbit monoclonal Runx3 antibody (1:1000, Abcam, ab224641), rabbit monoclonal p-p65 antibody (1:1000, Abcam, ab183559), rabbit monoclonal p-IкBa antibody (1:10000, Abcam, ab133462), rabbit monoclonal DNMT3B antibody (1:1000, Abcam, ab2851), rabbit monoclonal Suz12 antibody (1:2000, Abcam, ab12073). Then, the membranes were incubated with horseradish peroxidase (HRP)-conjugated goat anti-rabbit $\operatorname{IgG}(1: 3000$, Abcam, ab6721) for $1 \mathrm{~h}$ at room temperature. GAPDH were used as endogenous controls. The bands were visualized by using an ECL Plus Chemiluminescence Reagent Kit (Pierce, Rockford, IL, USA) and were photographed by a chemiluminescence imaging system. Image J software was used to quantify the band densities.

\subsection{Cell apoptosis assay}

Annexin V-FITC/PI double staining was used to analyze apoptosis on a flow cytometer (BD Bioscience, San Jose, CA, USA). After $48 \mathrm{~h}$ of transfection, the cells were detached with EDTA-free trypsin and collected afterwards. The cells were centrifuged for $5 \mathrm{~min}$ at $4{ }^{\circ} \mathrm{C}$ at $1000 \mathrm{rpm}$, and the supernatant was discarded. Apoptosis was detected by an Annexin V-FITC/PI Apoptosis Detection Kit (Beijing Solarbio Science \& Technology, Beijing, China). The cells were suspended in a mixture of AnnexinV-FITC and binding buffer (1:40) and incubated at room temperature for $30 \mathrm{~min}$. A mixture of PI and binding buffer (1:40) was then added and shaken, followed by incubation at room temperature for $15 \mathrm{~min}$. Fluorescence was detected by a flow cytometer, and the apoptosis rate was calculated and determined.

\subsection{Methylation-specific PCR}

Analysis of $\mathrm{CpG}$ island of Runx3 promoter region by using MethPrimer software (https://www.urogene.org/methprimer/)
Methylation-specific primers were designed to detect methylation of cytosine-phosphate-guanine $(\mathrm{CpG})$ islands of Runx 3 gene by MSP-PCR. DNA was extracted according to instructions provided by the pure gene DNA isolation kit (Qiagen, Hilden, Germany). Next, $1 \mathrm{ml}$ of DNA was added into $3 \mathrm{M} \mathrm{NaOH}$ to separate the DNA strands. DNA was then modified with CpGenome DNA Modification Kit (S7820; Millipore Sigma) and underwent MSP followed by PCR reaction on a Thermocycler (Biometra, Dublin, Ireland). The amplified products were subjected to $18 \mathrm{~g} / \mathrm{L}$ agarose gel electrophoresis, imaged by UV imager gel electrophoresis imaging, and analyzed by using a gel imager (FireReader, UVItec, Cambridge, United Kingdom).

\subsection{RNA Immunoprecipitation (RIP)}

RIP assay was performed to validate the binding between MIRT1 and Suz12. Cells were lysed by using RIP lysis buffer, and $100 \mu \mathrm{L}$ of the lysate was incubated with RIP buffer containing magnetic beads, which were conjugated with Suz12 antibodies (1:2000, ab12073, Abcam, Cambridge, UK) or control normal mouse immunoglobulin G (IgG; Millipore, Billerica, MA, USA). Among the antibodies, IgG was considered as a negative control. Proteinase K buffer was then added to the samples to digest protein. Finally, the bounded RNA was isolated from the beads by using Trizol reagent and purified RNA was assayed by using RT-qPCR.

\subsection{Chromatin Immunoprecipitation assay (ChIP)}

ChIP assay was conducted to verify the effects of DNMR3B on the Runx3 promoter region. Briefly, HL-1 cells were transfected with NC siRNA or MIRT1 siRNA for $48 \mathrm{~h}$. Then, DNA-protein complexes were cross-linked with $1 \%$ formaldehyde for $10 \mathrm{~min}$ at $37^{\circ} \mathrm{C}$. Then, cells were lysed in the lysate, and the chromatin DNA in the lysate was sonicated into fragments. Immune complexes were formed with either nonspecific IgG and DNMT3B antibodies. Precipitated chromatin DNA was detected by using RT-qPCR.

\subsection{Co-Immunoprecipitation (Co-IP)}

HL-1 cells were lysed by using RIPA buffer (Beyotime, Shanghai, China), and the supernatant was collected and incubated with Suz12 antibody or DNMT3B antibody at $4{ }^{\circ} \mathrm{C}$ overnight. Then the mixture was incubated with $100 \mu \mathrm{L}$ of protein $\mathrm{A} / \mathrm{G}$ agarose beads (Takara Biotechnology, Dalian, China) overnight at $4{ }^{\circ} \mathrm{C}$. Subsequently, the agarose beads-antigen-antibody complex was collected by instantaneous centrifugation and washed with PBS for three times. Next, the complex was boiled with protein loading buffer for $5 \mathrm{~min}$. The supernatant was collected by centrifugation and analyzed by using Western blotting to detect the expression of interaction proteins.

\subsection{Enzyme-Linked Immunosorbent Assay (ELISA)}

Mouse cardiomyocytes and mouse heart tissues were assayed for the contents of superoxide dismutase (SOD), malondialdehyde (MDA), interleukin-6 (IL-6) and tumor necrosis factor- $a$ (TNF- $\alpha$ ) and the enzymatic activity of DNMT3B by ELISA kits 
(Thermo Fisher Scientific, Waltham, Ma, USA), according to the manufacturer's instructions.

\subsection{Hemodynamic monitoring}

After the mouse hearts were washed with phosphate buffer solution and frozen for $30 \mathrm{~min}$, the LV (left ventricle) was cut into 5 pieces with cross-section. The hearts were incubated in $1 \% \mathrm{TTC}$ at $37^{\circ} \mathrm{C}$ for $15 \mathrm{~min}$ respectively, and subsequently fixed in $10 \%$ formalin solution. The infarct area (IFN) and area at risk (AAR) were identified by using a dissecting microscope. The IFN and AAR were calculated digitally, and the IFN was expressed as a percentage of the AAR and LV (IFN/AAR, IFN/LV). The mice were sedated by $3 \%$ isoflurane inhalation and then assessed by echocardiography (Sequoia Acuson, 15-MHz linear transducer; Siemens, Erlangen, Germany). Ejection fraction (EF) and fraction shortening (FS) were calculated by using computer algorithms.

\subsection{Statistical analysis}

All statistical results were analyzed by SPSS version 23.0 software. The measured data were presented as mean \pm standard error of mean (SEM). Students' $t$-test was used for comparative analysis between two groups, and analysis of variance (ANOVA) was performed for comparison among multiple groups. $P<0.05$ was regarded significant.

\section{Results}

\subsection{Astragaloside IV protects $H L-1$ cells from hypoxia-induced cell injury}

Figure 1A showed the chemical formula of AS-IV. To explore the effect of AS-IV on hypoxia-induced HL-1 cells, various doses of AS-IV $(2.5,5,10,50$ and $100 \mu \mathrm{g} / \mathrm{ml})$ were used to treat cells. We found that AS-IV $(2.5,5,10,50$ and $100 \mu \mathrm{g} / \mathrm{ml})$ had no
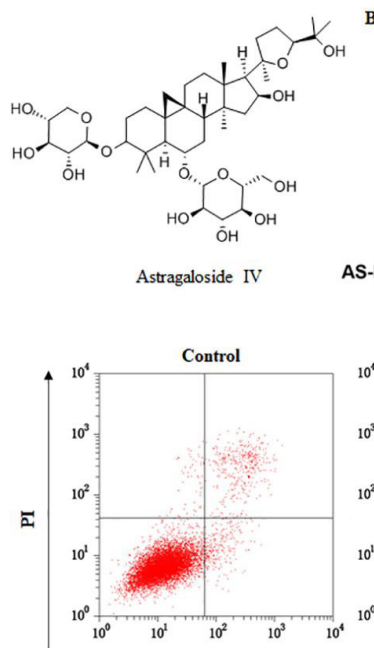

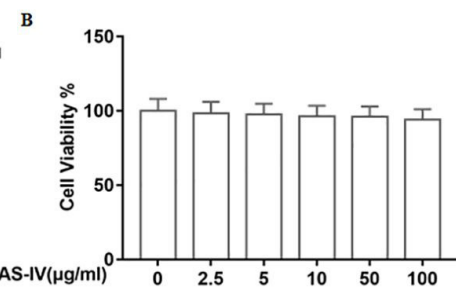

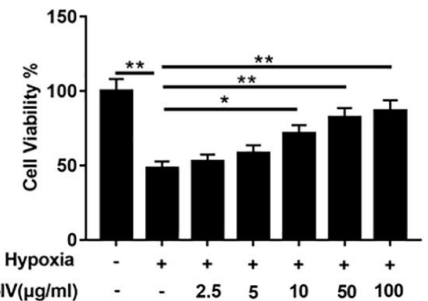

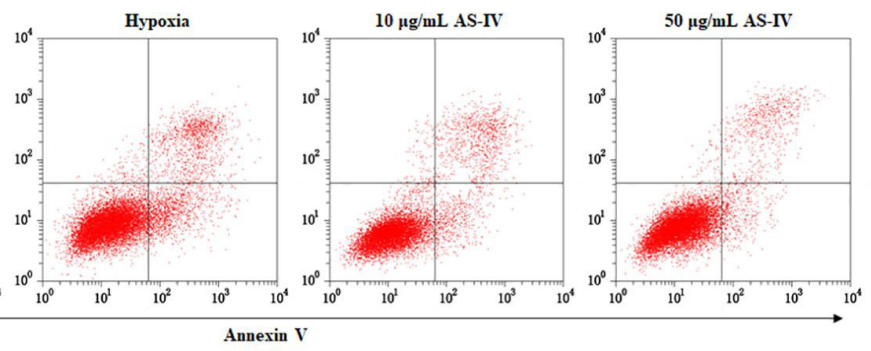

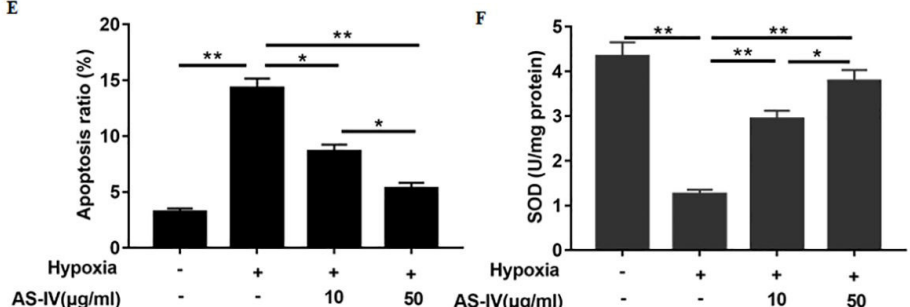

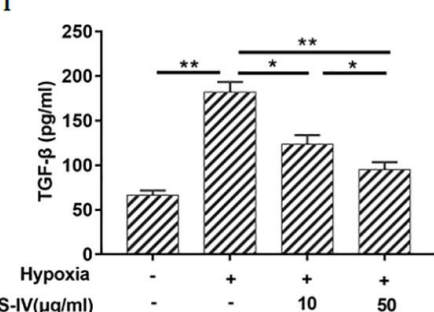

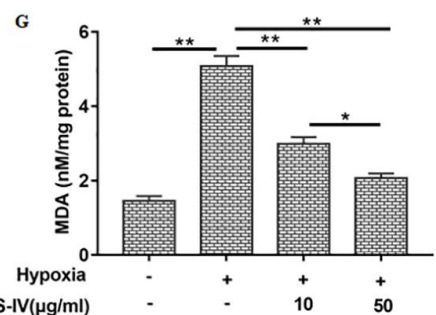

$\mathbf{J}$

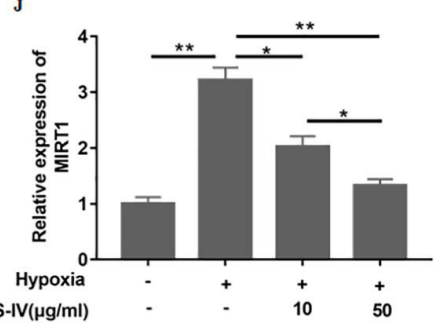

Figure 1. AS-IV protects HL-1 cells from hypoxia-induced cell injury. (A) The structural formula of AS-IV; (B) CCK-8 assay was used to detect the cell viability of HL-1 cells treated with different concentrations of AS-IV for $48 \mathrm{~h}$; (C) CCK-8 assay was used to detect the cell viability of hypoxia-treated cells incubated with different concentrations of AS-IV for $48 \mathrm{~h}$; (D) and (E) HL-1 cell apoptosis was examined by using flow cytometry. (F)-(I) The contents of SOD, MDA, IL- 6 and TNF- $\alpha$ were detected by using ELISA. (J) RT-qPCR was used to detect MIRT1 level in HL-1 cells; $(n=4)$; Data were presented as mean \pm SEM. ANOVA analysis was used for the comparison among groups, ${ }^{\star} P<0.05,{ }^{\star \star} P<0.01$. 
significant cytotoxicity on HL-1 cells (Figure 1B). Additionally, hypoxia induction significantly decreased cell viability $(P<0.01)$, whereas AS-IV at the concentrations of $10 \mu \mathrm{g} / \mathrm{ml}, 50 \mu \mathrm{g} / \mathrm{ml}$ and $100 \mu \mathrm{g} / \mathrm{ml}$ was able to observably increase cell viability (Figure $1 \mathrm{~B}, P<0.05$ ). Thus, 10 and $50 \mu \mathrm{g} / \mathrm{ml}$ of AS-IV were selected for use the following investigations. Flow cytometry results showed that the apoptosis rate was significantly increased in hypoxia-treated cells, whereas AS-IV intervention could observably reduce the apoptosis rate of HL-1 cells induced by hypoxia in a dose-dependent manner (Figure 1D, E, $P<0.05$ ). In addition, SOD secretion was decreased, and MDA, IL- 6 and TNF- $\alpha$ secretion were elevated in hypoxia treated cells compared with the control group, while AS-IV intervention could reverse these effects, indicating that AS-IV in hypoxia-treated cells may play a role of anti-oxidant and anti-inflammatory (Figure 1F-I, $P<0.05)$. RT-qPCR results indicated that MIRT1 expression was memorably reduced by treatment with AS-IV in hypoxia-treated cells in a dose-dependent manner (Figure 1J, $P<0.05$ ).

\subsection{AS-IV protects $H L-1$ cells from hypoxia-induced cell injury by downregulating IncRNA MIRT1}

The pcDNA-MIRT1 was transfected into $50 \mu \mathrm{g} / \mathrm{mL}$ AS-IV incubated cells in the present of hypoxia treatment. The results showed that MIRT1 was over-expressed in hypoxia-treated HL-1 cells compared with normal cells (Figure $2 \mathrm{~A}, P<0.01$ ). Transfection of pcDNA-MIRT1 could significantly increase the MIRT1 level in hypoxia-treated HL-1 cells compared with AS-IV treated (Figure $2 \mathrm{~B}, P<0.01$ ). Overexpression of MIRT1 inhibited cell

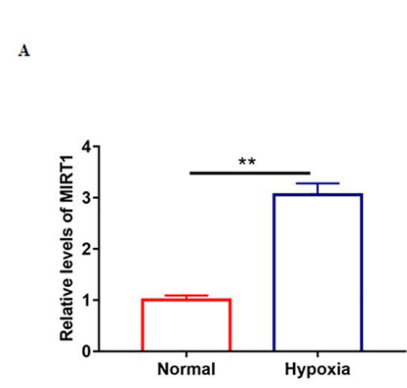

D

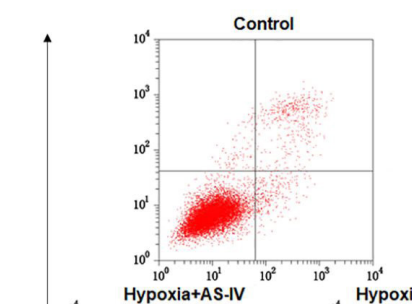

control

$\square$ Hypoxia

Hypoxia+AS-IV

曰 Hypoxia+AS-IV+vector

Hypoxia+AS-IV+pcDNA-MIRT1
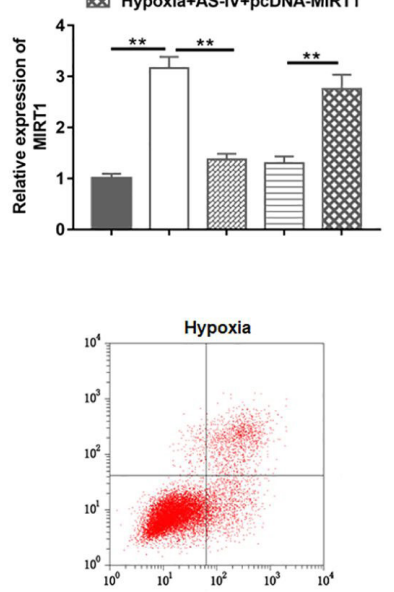

$10^{4} \quad$ Hypoxia+AS-IV $10^{4}$ Hypoxia+AS-IV+Vector Hypoxia+AS-IV+pcDNA-MIRT1
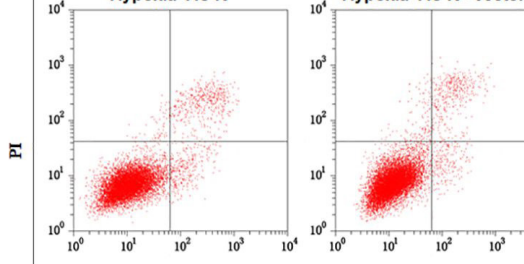

$10^{2}$
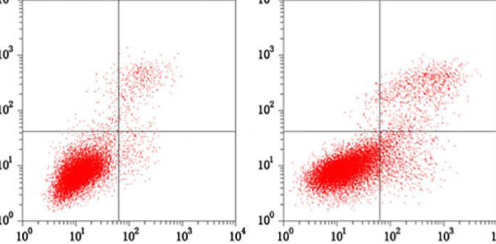

Annexin V

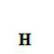

G

$\square$ control

Hypoxia+AS-IV

$\boxminus$ Hypoxia+AS-IV+vector

国 Hypoxia+AS-IV+pcDNA-MIRT1

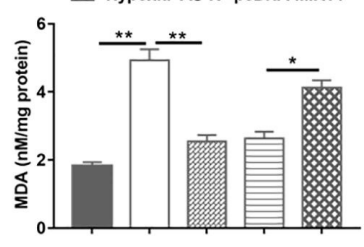

$\square$ Hypoxi

[3.

$\boxminus$ Hypoxia+AS-IV+vector

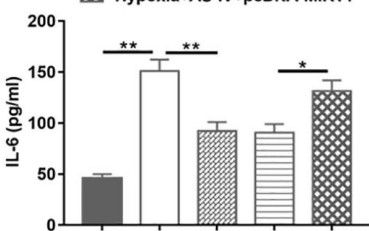
Hypoxia+AS-IV+pcDNA-MIRT1
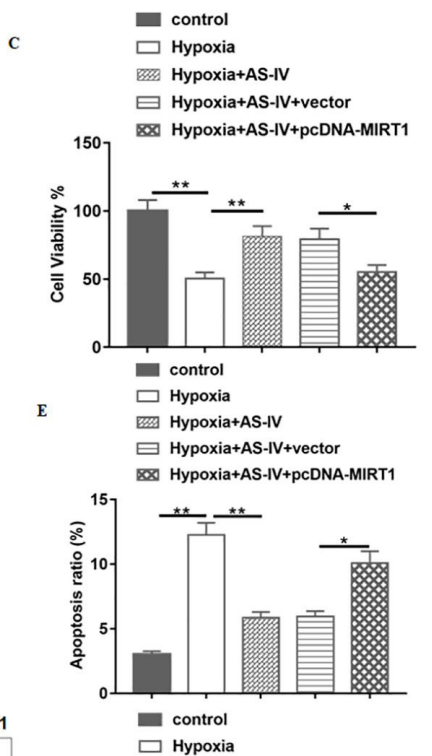

F Hypoxia+AS-IV

$\boxminus$ Hypoxia+AS-IV+vector

Q Hypoxia+AS-IV+pcDNA-MIRT1

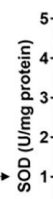

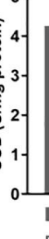

$\square$ нурох

Hypoxia+AS-IV

$\boxminus$ Hypoxia+AS-IV+vector

Hypoxia+AS-IV+pcDNA-MIRT1

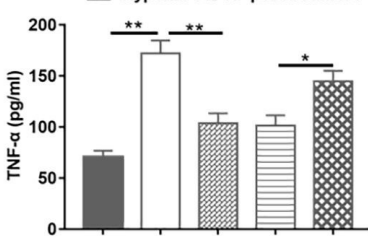

Figure 2. AS-IV protects HL-1 cells from hypoxia-induced cell injury by downregulating lncRNA MIRT1. (A) The expression of MIRT1 in HL-1 cells and hypoxia-treated HL-1 cells was detected by RT-qPCR, the pcDNA-MIRT1 (200 nM) was transfected into $50 \mu \mathrm{g} / \mathrm{mL}$ AS-IV incubated cells in the present of hypoxia treatment for $24 \mathrm{~h}$; (B) The expression of MIRT1 in hypoxia-treated HL-1 cells was detected by RT-qPCR; (C) The cell viability was detected by CCK-8; (D) and (E) HL-1 cell apoptosis was examined by using flow cytometry; (F)-(I) The contents of SOD, MDA, IL- 6 and TNF- $\alpha$ were detected by using ELISA; $(n=4)$; Data were presented as mean \pm SEM; $t$-test was used to compare differences between two groups; ANOVA analysis was used for the comparison among groups, ${ }^{\star} P<0.05,{ }^{\star *} P<0.01$. 
proliferation, and promoted cell apoptosis in hypoxia-treated HL-1 cells compared with AS-IV treatment (Figure 2C-E, $P<0.05$ ). In addition, Transfection of pcDNA-MIRT1 memorably decreased SOD secretion $(P<0.01)$, and increased secretion of MDA $(P<$ $0.05)$, IL-6 $(P<0.05)$ and TNF- $\alpha(P<0.05)$ in hypoxia-treated HL-1 cells compared with AS-IV treatment (Figure 2F-I).

\subsection{MIRT1 facilitates DNMT3B-mediated Runx3 promoter methylation by binding with Suz12}

To further investigate the underlying mechanism of MIRT1 in the regulation of hypoxia-treated HL-1 cell behaviors, we focused on the MIRT1 downstream pathway. RIP results showed that MIRT1 could combine with Suz12 (Figure 3A, $P<0.01$ ). MIRT1 overexpression markedly upregulated the expression of Suz12, whereas MIRT1 inhibition had the opposite effect on
Suz12 expression (Figure 3B, $P<0.01$ ). Co-IP results displayed that DNMT3B was a binding protein of Suz12 (Figure 3C). Furthermore, upregulation of MIRT1 resulted in elevated enzymatic activity of DNMT3B, which was reduced when MIRT1 was interfered (Figure 3D, $P<0.01$ ). We conducted ChIP assay and the results showed that DNMT3B could bind to promoter region of Runx3, and silencing MIRT1 prominently attenuated DNMT3B enrichment (Figure 3E, $P<0.01$ ). MIRT1 overexpression increased Runx3 promoter region methylation and restrained Runx3 expression, whereas MIRT1 inhibition decreased Runx3 promoter region methylation and facilitated Runx3 expression. Furthermore, MIRT1 overexpression significantly reversed the inhibitory effect of DNMT3B inhibitor SGI-1027 on Runx3 promoter methylation rate as well as the promoting effect on Runx3 protein level (Figure 3F-H, $P<0.01$ ).
A
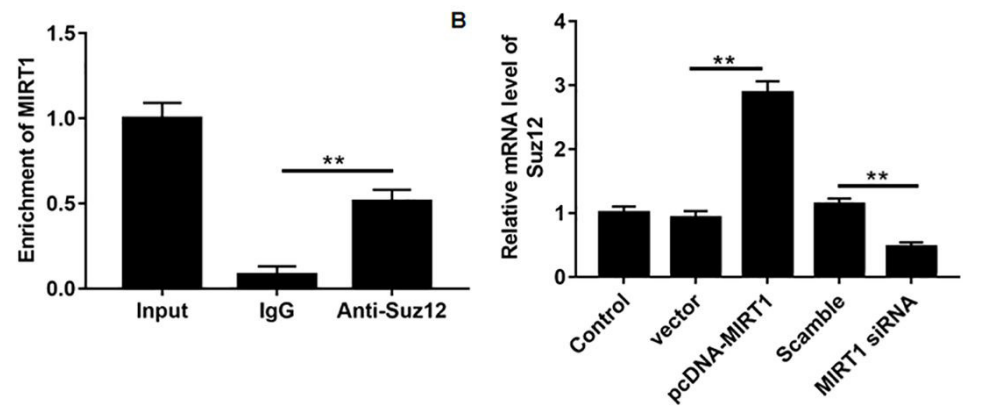

D

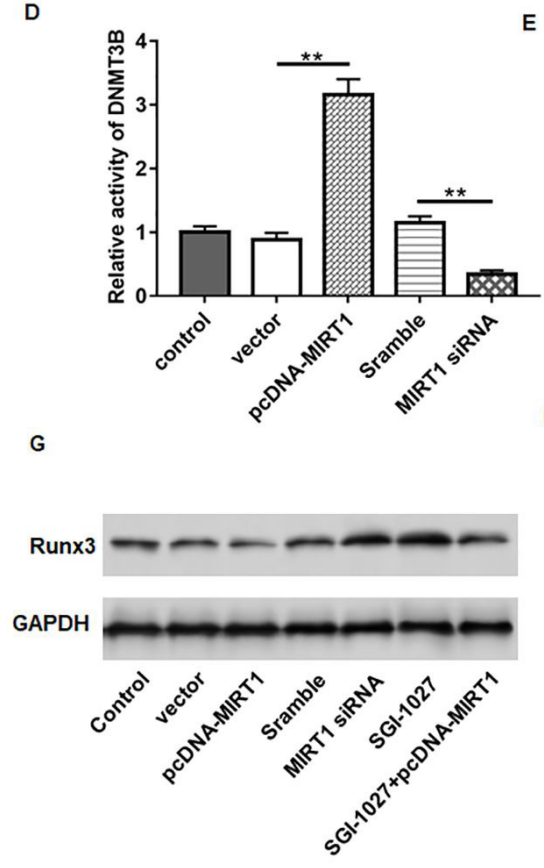

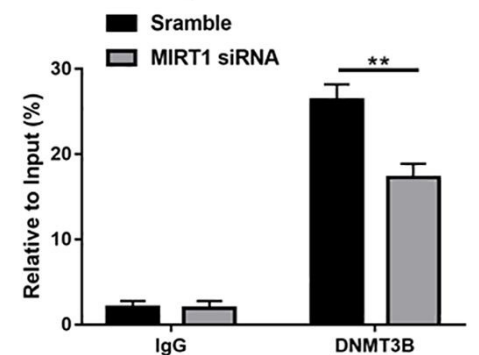

H.

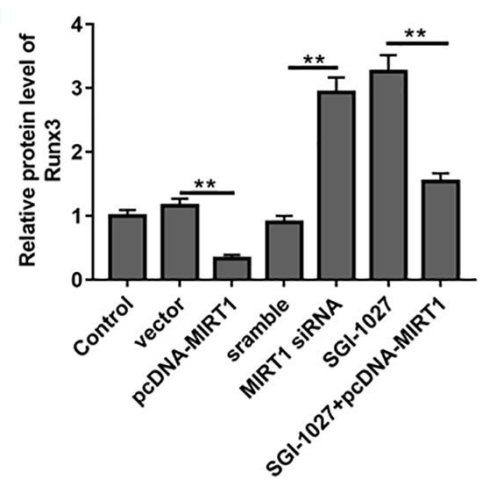

c
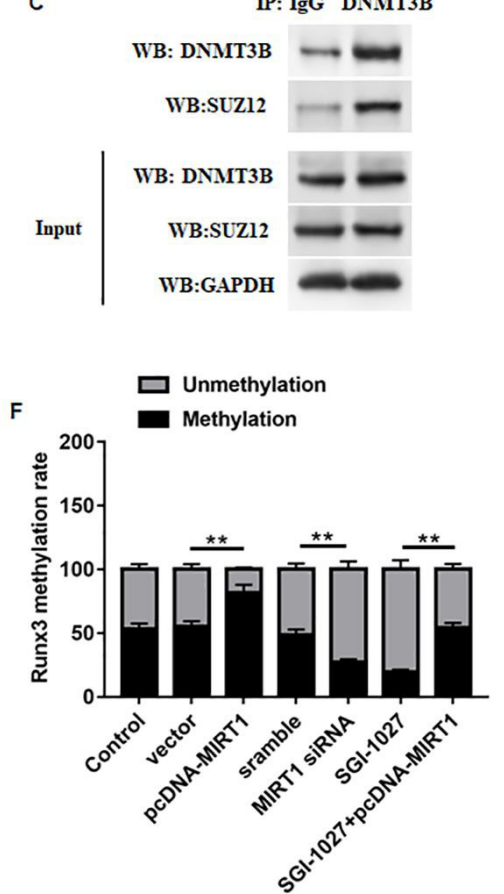

Figure 3. MIRT1 facilitates DNMT3B-mediated Runx3 promoter methylation by binding with Suz12. (A) RIP assay was used to detect the enrichment of MIRT1 on Suz12; (B) pcDNA-MIRT1 (200 nM) and MIRT1 siRNA (200 nM) were transfected into HL-1 cells for 24 h, and then the expression of Suz12 in HL-1 cells was detected by RT-qPCR; (C) Co-IP was used to determine the binding relationship between Suz12 and DNMT3B; (D) Detection of KDM3B activity in HL-1 cells by ELSA; (E) The level of DNMT3B in the promoter region of Runx3 was assessed by ChIP assay; (F) MSP-PCR assay was used to detect the methylation level of Runx3 promoter region in HL-1 cells; (G) and (H) Western blotting was used to detect the protein level of Runx3 in HL-1 cells; SGI-1027: DNMT3B inhibitor; $(\mathrm{n}=4)$; Data were presented as mean \pm SEM. ANOVA analysis was used for the comparison among groups, ${ }^{* *} P<0.01$. 


\subsection{Inhibition of Runx 3 aggravates hypoxia-induced cardiomyocyte injury}

To evaluate the function of Runx3, MIRT1 siRNA alone or together with Runx3 siRNA were transfected into hypoxia-treated HL-1 cells. Overexpression of MIRT1 observably inhibited protein level of Runx3 (Figure 4A, $P<0.01$ ). Furthermore, we found that downregulation of Runx 3 reversed the promoting effect of MIRT1 interference on cell proliferation and the inhibitory effect on apoptosis in hypoxia-treated HL-1 cells (Figure 4B-D, $P<0.01$ ). Downregulation of Runx 3 could reverse the promoting effect of
MIRT1 inhibition on SOD secretion and the inhibitory effect on secretion of MDA, IL-6, and TNF- $\alpha$ in hypoxia-treated HL- 1 cells (Figure $4 \mathrm{E}-\mathrm{H}, P<0.01$ ). It is well known that NF- $\kappa \mathrm{B}$ signaling plays an important role in promoting proinflammatory factor secretion, which mediates the inflammatory response (Thoma \& Lightfoot, 2018). Western blotting results demonstrated that the expression of p-p65 and p-IкBa was observably decreased in hypoxia-treated HL-1 cells compared with normal cells. Transfection of MIRT1 siRNA could inhibit the expression of phosphorylated-p65 (p-p65) and p-IкBa in HL-1 cells treatment with hypoxia, which was reversed by Runx3 transfection (Figure 4I,

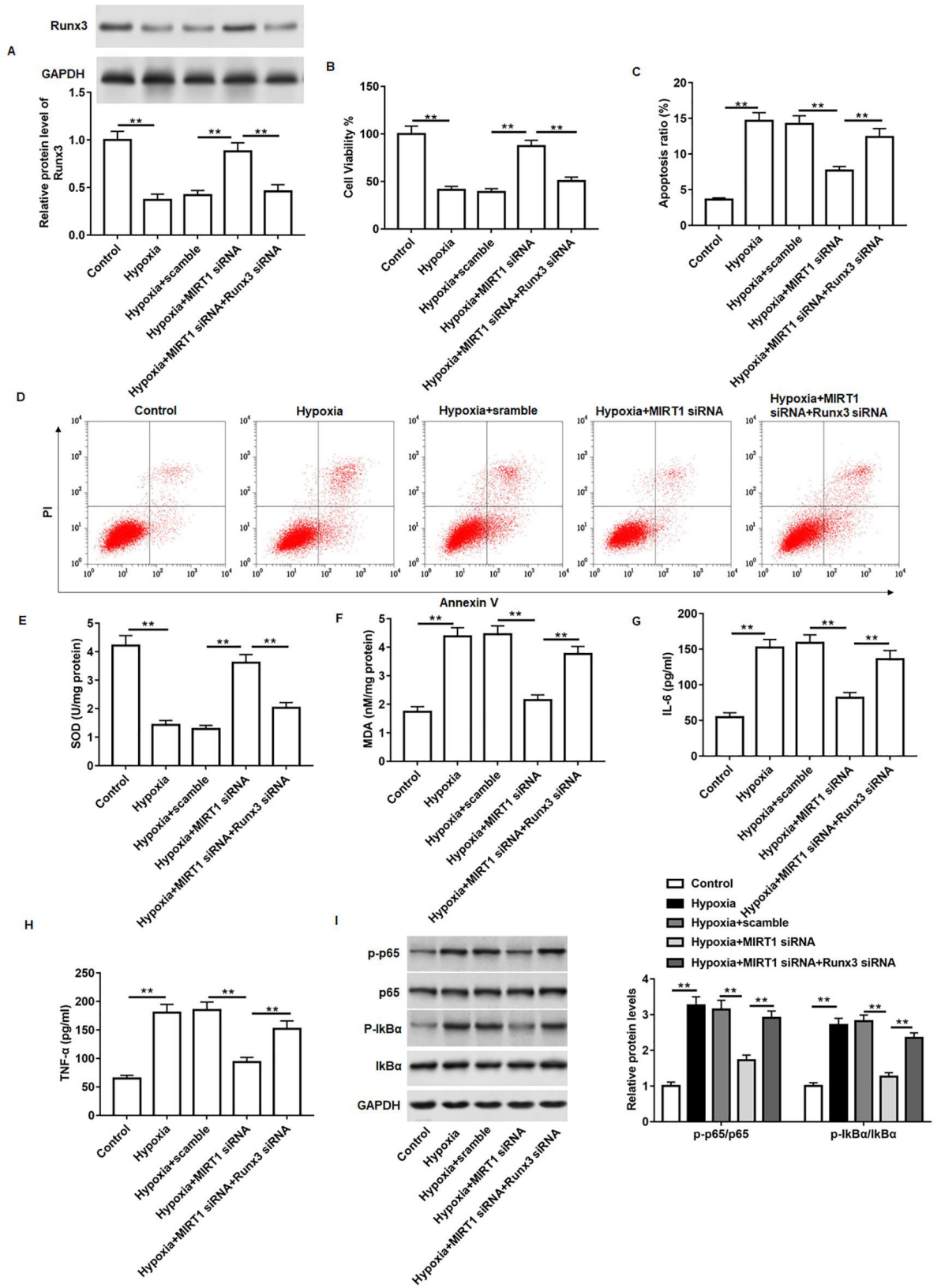

Figure 4. Inhibition of Runx3 aggravates hypoxia-induced cardiomyocyte injury. MIRT1 siRNA (200 nM) alone or together with Runx3 siRNA $(200 \mathrm{nM})$ were transfected into hypoxia-treated HL-1 cells for $24 \mathrm{~h}$. (A) Western blotting was used to detect the protein level of Runx3 in HL-1 cells; (B) The cell viability was detected by CCK-8; (C) and (D) HL-1 cell apoptosis was examined by using flow cytometry; (E)-(H) The contents of SOD, MDA, IL- 6 and TNF- $\alpha$ were detected by using ELISA; (I) The protein levels of p-p65 and p-IkBa were determined by Western blotting; $(\mathrm{n}=4)$; Data were presented as mean \pm SEM. ANOVA analysis was used for the comparison among groups, ${ }^{* *} P<0.01$. 
$P<0.01$ ), indicating that the NF- $\kappa B$ signaling pathway might be involved in the regulation of MIRT1 on MI.

\subsection{AS-IV protects hypoxia-induced cardiomyocyte injury by inhibiting the NF- $\mathrm{KB}$ signaling pathway}

To further validate the role of the NF- $\mathrm{kB}$ pathway in the regulation of MI by AS-IV treatment, hypoxia-treated cells were incubated with the NF- $\mathrm{kB}$ pathway activator (Betulinic acid) and $50 \mu \mathrm{g} / \mathrm{mL}$ AS-IV alone or together. The results showed that the levels of p-p65 and p-IкBa were substantially inhibited after treatment with AS-IV, whereas p-p65 and p-ІкBa expression was reversed and upregulated after using the NF- $\kappa B$ pathway activator (Betulinic acid) (Figure 5A-C, $P<0.01$ ).
Additionally, betulinic acid treatment was able to reverse the promoting effect on cell proliferation and the inhibiting effect on apoptosis of cells incubated with AS-IV (Figure 5D, E, G, $P<0.01$ ). Betulinic acid treatment reversed the promoting effect of AS-IV incubation on SOD secretion and the inhibitory effect on secretion of MDA, IL- 6 , and TNF- $\alpha$ in hypoxia-treated HL-1 cells (Figure 5F and H-J, $P<0.01$ ).

\subsection{AS-IV treatment improves cardiac function in MI mice}

Consistent with the in vitro results, the expression of MIRT1 was significantly upregulated and Runx 3 was downregulated in MI mice compared with sham mice $(P<0.01)$, whereas AS-IV dose-dependently decreased MIRT1 expression and upregulated

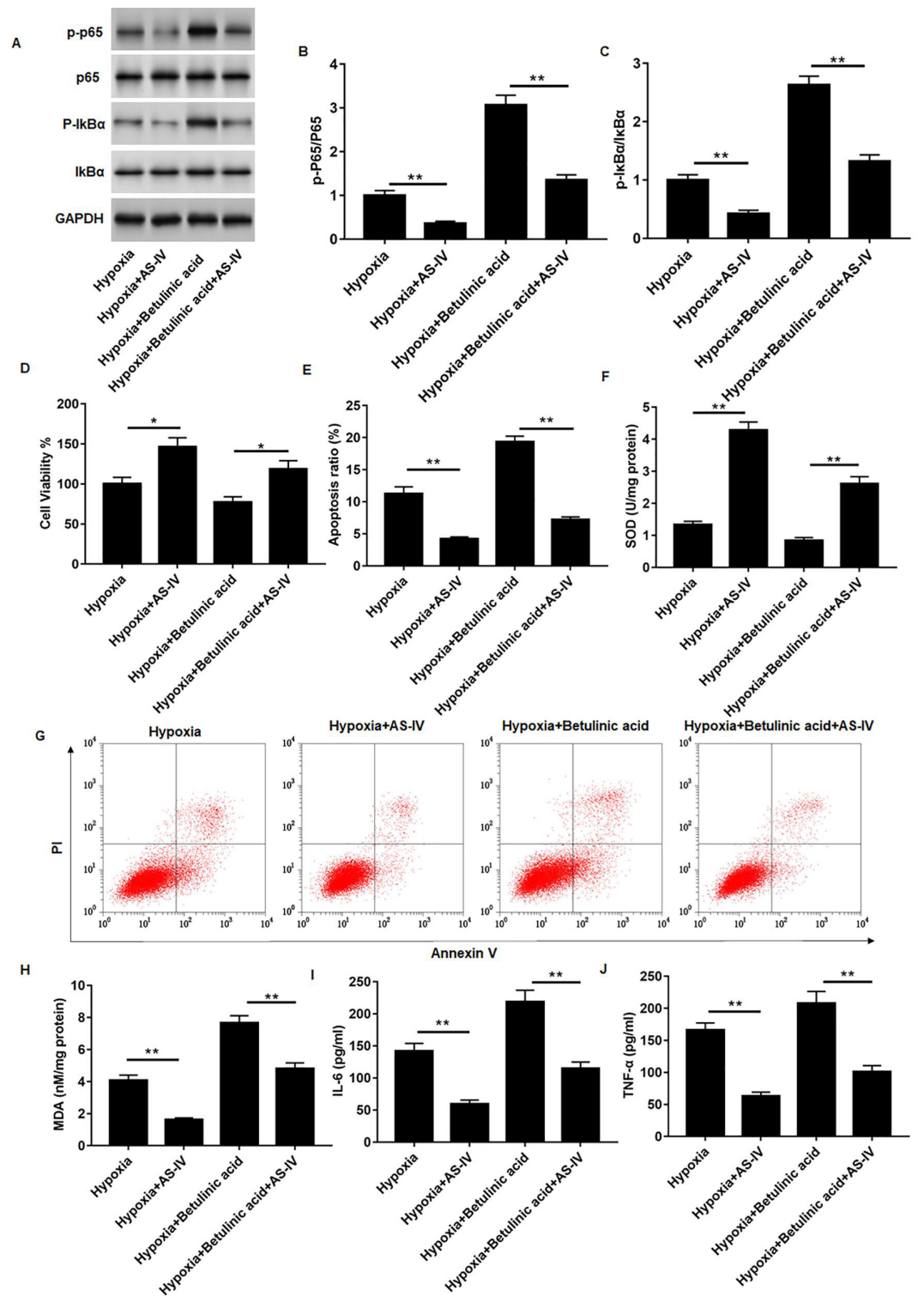

Figure 5. AS-IV protects hypoxia-induced cardiomyocyte injury by inhibiting the NF- $\kappa$ B signaling pathway. Hypoxia-treated cells were incubated

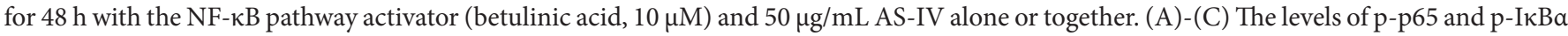
were determined by Western blotting; (D) The cell viability was detected by CCK-8; (E) and (G) HL-1 cell apoptosis was examined by using flow cytometry; (F) and (H)-(J) The contents of SOD, MDA, IL- 6 and TNF- $\alpha$ were detected by using ELISA; $(\mathrm{n}=4)$; Data were presented as mean \pm SEM. ANOVA analysis was used for the comparison among groups, ${ }^{* *} P<0.01$. 
Runx3 protein level (Figure 6A, B, $P<0.05$ ). Additionally, the contents of SOD were significantly inhibited and MDA, IL-6 and TNF- $\alpha$ was increased in MI mice compared with sham mice $(P<0.01)$, whereas AS-IV treatment reversed these effects in a dose-dependent manner (Figure 6C-F, $P<0.05$ ). Furthermore, AS-IV treatment markedly reduced the ratio of INF/AAR and INF/LV in mice with a dose-dependent manner compared with MI mice (Figure 6G, $P<0.01$ ). Moreover, echocardiographic examinations were performed to determine the effect of AS-IV on cardiac function. FS and EF were significantly lower in MI group compared with Sham group, whereas cardiac function was improved in a dose-dependent manner after AS-IV treatment (Figure 6H, I, $P<0.01$ ).

\section{Discussion}

MI has been defined as cardiomyocyte death due to prolonged ischemia (Zeymer, 2019). AS-IV is a common drug used to prevent and treat cardiovascular and cerebrovascular ischemia. It has been reported that AS-IV may protect cardiomyocytes
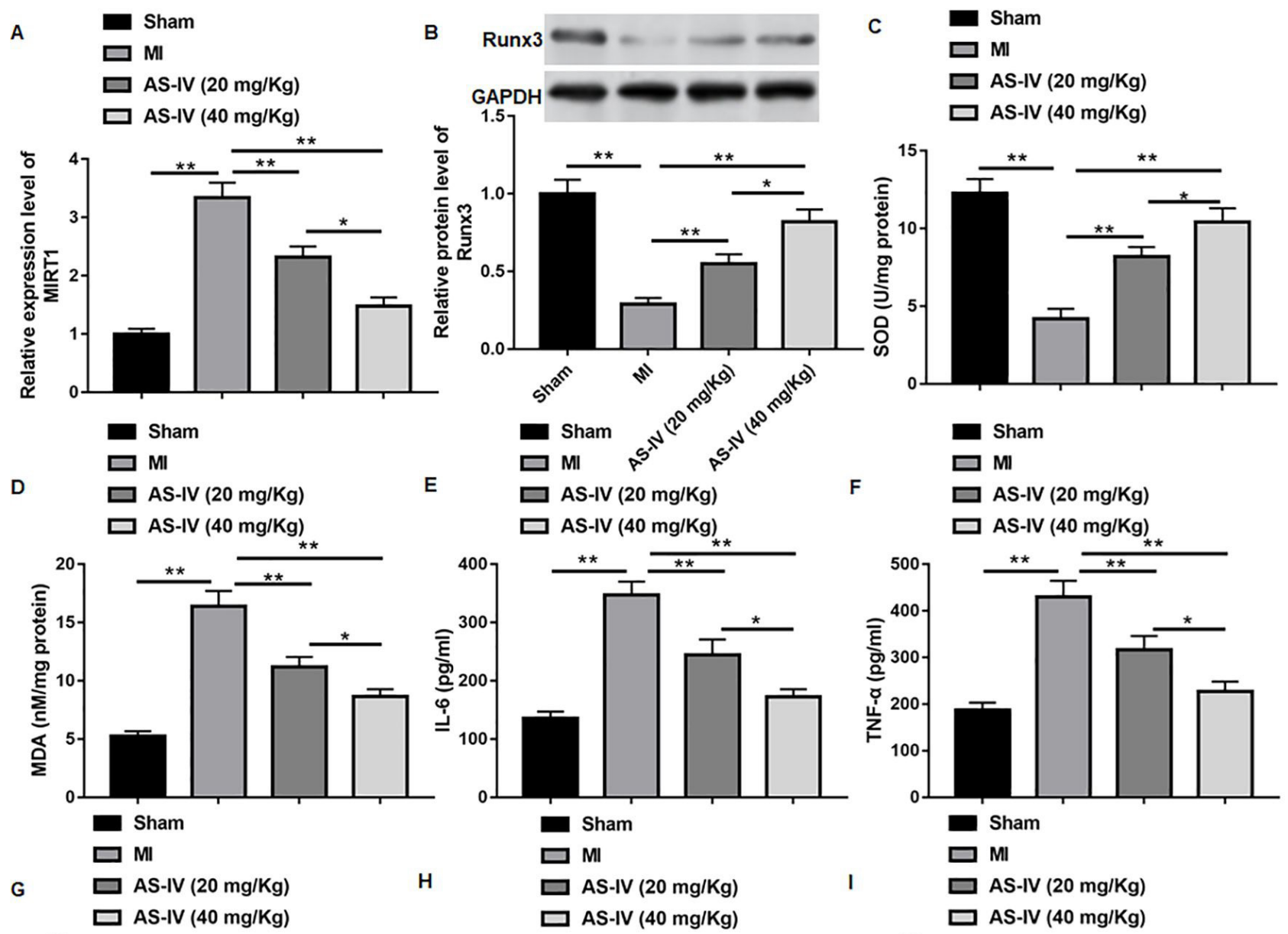

$\mathbf{F}$
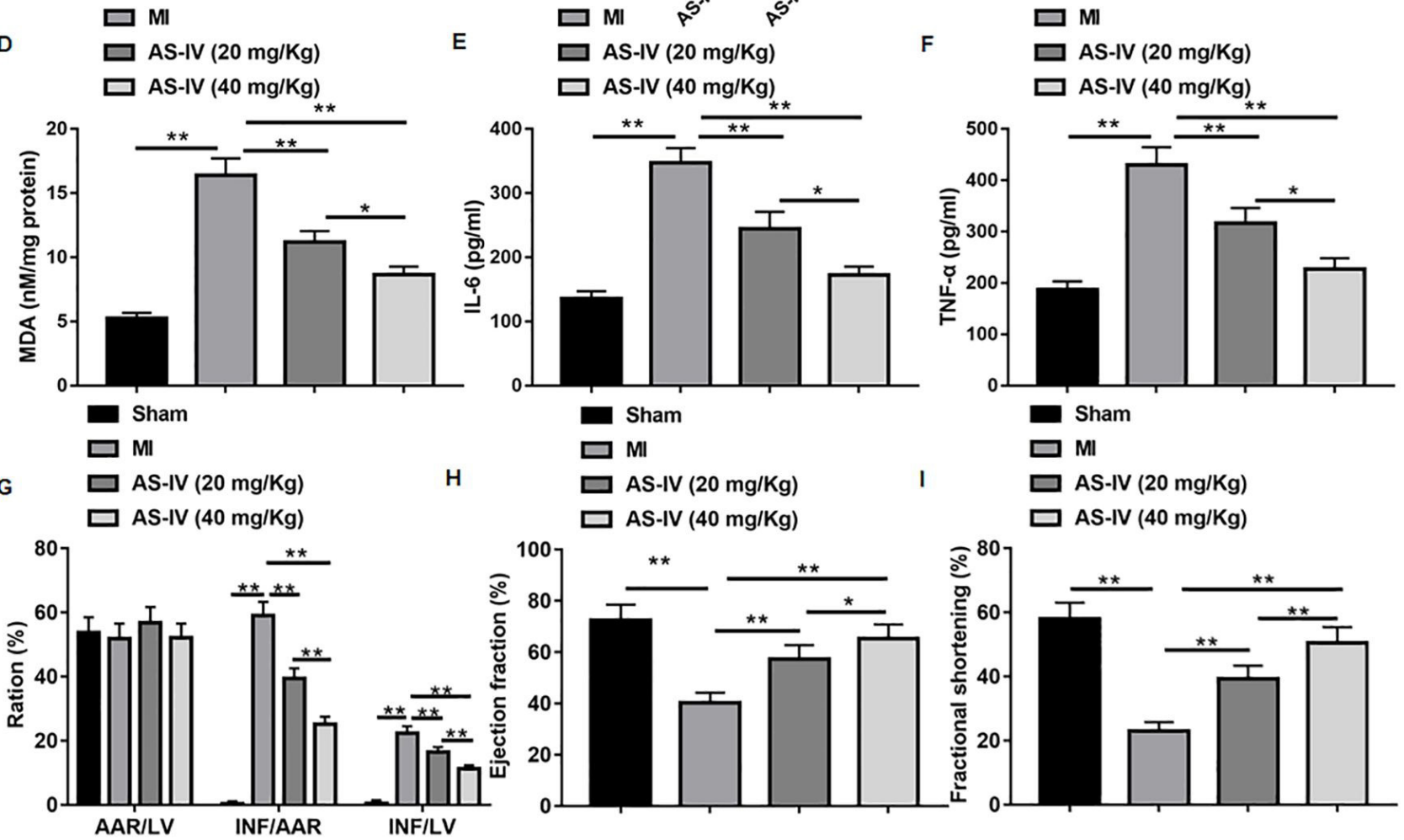

Figure 6. AS-IV treatment improves cardiac function in MI mice. (A) RT-qPCR was used to detect the expression level of MIRT1 in mouse heart tissues; (B) The protein level of Runx3 in mouse heart tissues was determined by Western blotting; (C)-(F) The contents of SOD, MDA, IL-6 and TNF- $\alpha$ in mice serum were detected by using ELISA; (G) The IFN/AAR and IFN/LV percentage of left ventricular cross section of mice were observed and calculated; LV: left ventricle; INF: infarct area; AAR: area at risk. (E) and (F) Echocardiography was used to evaluate FS and EF in the left ventricle of mice; FS: fractional shortening; EF: ejection fraction. Data were presented as mean \pm SEM. ANOVA analysis was used for the comparison among groups, ${ }^{*} P<0.05,{ }^{* *} P<0.01$. 
against hypoxia induced injury by activating PI3K/Akt and MAPK/ERK signaling pathways (Gong et al., 2018). The present study found that 10,50 and $100 \mathrm{ug} / \mathrm{ml}$ of AS-IV protected HL-1 cells from hypoxia-induced injury by dose dependently enhancing cell viability and inhibiting cell apoptosis. Hypoxia-induced alteration was significantly abrogated by AS-IV. Moreover, AS-IV was also reported to inhibits Inflammatory factor release in LPS-stimulated HL-1 cells (Wang et al., 2015), which stands for the similar point with our data. In this study, we found that AS-IV reduced IL-6, TNF- $\alpha$ and MDA secretion in a dose-dependent manner. Hundreds of lncRNAs have been reported to play an important role in cardiovascular diseases, especially in ischemic cardiomyopathy (Liao et al., 2016). LncRNA MIRT1, first identified by Zangrando and his team in previous studies, was significantly upregulated during MI (Zangrando et al., 2014). Data suggested that the protective effects of MIRT1 inhibition in MI may be resulted from the inhibition of NF- $\kappa B$ activation by reducing the levels of proinflammatory cytokines, which might control the inflammatory response and induce cell apoptosis (Liu et al., 2019). Furthermore, many lncRNAs have been shown to be involved in the regulation process of MI by AS-IV treatment. It has been reported that lncRNA GAS5 expression was down-regulated in HL-1 cells under AS-IV stimulation. More experiments reflected that effects of AS-IV on hypoxia-treated HL-1 cells could be bated by lncRNA GAS5 overexpression, indicating that AS-IV might function through down-regulation of lncRNA GAS5 (Du et al., 2019). Considering the effects of AS-IV and MIRT1 on contents of IL-6, TNF- $\alpha$, SOD and MDA, we hypothesized that there might be a correlation between AS-IV and MIRT1. In the present study, the expression of MIRT1 was downregulated in hypoxia-treated HL-1 cells under AS-IV stimulation. Overexpression of MIRT1 reversed cell functions in hypoxia-treated HL-1 cells compared with AS-IV treatment.

So next, we explored the possible pathway of MIRT1 in MI. SUZ12 who is indicated as the suppressor of zeste- 12 protein has been found could regulate cell density -dependent proliferation and the inflammatory response through regulating IL-1 $\beta$ -dependent inflammatory response. A previous study found that knockdown of lncRNA PCAI protects against cognitive decline induced by hippocampal neuroinflammation via binding with and negatively regulating SUZ12 (Chen et al., 2020). In this study, we found that MIRT1 downregulated Suz12 expression by binding to Suz12 protein. DNA methylation is essential for a variety of physiological activities, including gene silencing, genomic imprinting, chromatin modification, and X chromosome inactivation [13]. DNA methylation occurs mainly at $\mathrm{CpG}$ dinucleotides. DNA methylation is mediated by several known DNA methyltransferases (DNMTs), including the maintenance enzyme DNMT1 and the de novo methyltransferases DNMT3A/3B. The progression of heart disease has been shown to be associated with aberrations in genomic DNA methylation (Agha et al., 2019). Additionally, Suz12 could mediate silencing of universally imprinted genes by maintaining allele-specific methylation, and promote DNA methylation in promoter regions by recruiting DNMTs (Bahar et al., 2014). Silibinin reduces DNMT1 activity by inhibiting the expression of SUZ12, thereby achieving anti-tumor effects (Anestopoulos et al., 2016). A study has demonstrated that DNMT enable CCND2 and
Runx3 to undergo hypermethylation in the promoter region of breast cancer (Oh et al., 2017). We found that MIRT1 could bind Suz12 protein, enabling Suz12 to recruit DNMT3B in the Runx3 promoter region to promote Runx3 methylation and downregulate Runx3 expression.

Runx3 is a transcription factor that may be involved in cell proliferation and differentiation (Chen et al., 2016). It was found to be a novel anti-tumor gene silenced by its hypermethylated promoter in pancreas cancer (Whittle \& Hingorani, 2017). Upregulation of Runx 3 can inhibit the proliferation and metastasis of gastric cancer and may serve as a new target for cancer therapy (Yu et al., 2017). Studies have reported that DNMT3B could regulate the expression level of Runx3 by altering the DNA methylation of Runx3 in prostate cancer cells involved in prostate cancer progression (Yang et al., 2020). MiR-148a may improve cell proliferation and invasion by regulating Runx3 expression through regulating DNMT3B dependent DNA methylation in gastric cancer, providing a new regimen for gastric cancer therapy (Zuo et al., 2013). Moreover, inhibition of Runx3 methylation provides protective effects against cardiac microvascular endothelial cell damage and inflammatory responses in MI, which may be a promising target for MI treatment (Wang et al., 2019). Therefore, we speculate that analysis of Runx3 levels may help to reflect the significance of up-regulation or down-regulation of Runx3 in MI development. The results found that overexpression of MIRT1 observably inhibited protein level of Runx3. Furthermore, downregulation of Runx3 reversed the promoting effect of MIRT1 interference on cell functions in hypoxia-treated HL-1 cells.

In addition, the mechanism by which AS-IV was found to be involved in the regulation of MI in our study may be related to the inhibition of the NF- $\mathrm{KB}$ signaling pathway activation. $\mathrm{NF}-\mathrm{\kappa B}$ is a family of transcription factors that controls many cellular processes in disease, such as inflammation, proliferation, as well as angiogenesis. A recent study has shown that blocking NF- $\kappa B$ could protect the heart against inflammatory responses and acute ischemic injury (Hou et al., 2021). Previous studies have elucidated that AS-IV could inhibit high glucose-induced NLRP3 inflammasome activation and subsequent secretion of pro-inflammatory cytokines via inhibiting TLR4/NF- $\kappa B$ signaling pathway and CaSR, which provides new insights into the anti-inflammatory activity of AS-IV (Leng et al., 2019). In addition, MIRT1 inhibition attenuated MI injury presumably by decreasing cardiomyocytes apoptosis and reducing inflammatory cell infiltration. These effects could be attributed, at least partly, to inhibition of the NF- $\mathrm{\kappa B}$ pathway, resulting in decreased expression of inflammatory factors (Li et al., 2017b). This is consistent with the results of our experiment. The results showed that the levels of p-p65 and p-IкBa were substantially inhibited after treatment with AS-IV. The NF- $\kappa B$ pathway activator betulinic acid treatment was able to reverse the functions of cells incubated with AS-IV.

In conclusion, AS-IV treatment inhibits DNMT3B-mediated Runx3 promoter methylation by restraining Suz12 expression and further blocks the NF- $\mathrm{kB}$ signaling pathway, and in turn improves the cardiac functions of mice with MI. These findings contribute to a broader and deeper understanding of the mechanisms of 
AS-IV and MIRT1 in the development of MI and to the search for a new target for the treatment of MI.

\section{Conflict of interest}

The authors declare that they have no competing interests.

\section{References}

Agha, G., Mendelson, M. M., Ward-Caviness, C. K., Joehanes, R., Huan, T., Gondalia, R., Salfati, E., Brody, J. A., Fiorito, G., Bressler, J., Chen, B. H., Ligthart, S., Guarrera, S., Colicino, E., Just, A. C., Wahl, S., Gieger, C., Vandiver, A. R., Tanaka, T., Hernandez, D. G., Pilling, L. C., Singleton, A. B., Sacerdote, C., Krogh, V., Panico, S., Tumino, R., Li, Y., Zhang, G., Stewart, J. D., Floyd, J. S., Wiggins, K. L., Rotter, J. I., Multhaup, M., Bakulski, K., Horvath, S., Tsao, P. S., Absher, D. M., Vokonas, P., Hirschhorn, J., Fallin, M. D., Liu, C., Bandinelli, S., Boerwinkle, E., Dehghan, A., Schwartz, J. D., Psaty, B. M., Feinberg, A. P., Hou, L., Ferrucci, L., Sotoodehnia, N., Matullo, G., Peters, A., Fornage, M., Assimes, T. L., Whitsel, E. A., Levy, D., \& Baccarelli, A. A. (2019). Blood Leukocyte DNA methylation predicts risk of future myocardial infarction and coronary heart disease. Circulation, 140(8), 645-657. http://dx.doi.org/10.1161/ CIRCULATIONAHA.118.039357. PMid:31424985.

Anestopoulos, I., Sfakianos, A. P., Franco, R., Chlichlia, K., Panayiotidis, M. I., Kroll, D. J., \& Pappa, A. (2016). A novel role of silibinin as a putative epigenetic modulator in human prostate carcinoma. Molecules, 22(1), 62. http://dx.doi.org/10.3390/molecules22010062. PMid:28042859.

Bahar, K. H., Vana, T., \& Walker, M. D. (2014). Paradoxical role of DNA methylation in activation of FoxA2 gene expression during endoderm development. The Journal of Biological Chemistry, 289(34), 2388223892. http://dx.doi.org/10.1074/jbc.M114.573469. PMid:25016019.

Boateng, S., \& Sanborn, T. (2013). Acute myocardial infarction. Disease-a-Month, 59(3), 83-96. http://dx.doi.org/10.1016/j. disamonth.2012.12.004. PMid:23410669.

Chen, F., Liu, X., Bai, J., Pei, D., \& Zheng, J. (2016). The emerging role of RUNX3 in cancer metastasis [Review]. Oncology Reports, 35(3), 1227-1236. http://dx.doi.org/10.3892/or.2015.4515. PMid:26708741.

Chen, L., Yao, H., Chen, X., Wang, Z., Xiang, Y., Xia, J., Liu, Y., \& Wang, Y. (2018). Ginsenoside Rg1 decreases oxidative stress and downregulates Akt/mTOR signalling to attenuate cognitive impairment in mice and senescence of neural stem cells induced by D-Galactose. Neurochemical Research, 43(2), 430-440. http://dx.doi.org/10.1007/ s11064-017-2438-y. PMid:29147958.

Chen, W., Gao, N., Shen, Y., \& Cen, J. N. (2010). Hypermethylation downregulates Runx3 gene expression and its restoration suppresses gastric epithelial cell growth by inducing p27 and caspase 3 in human gastric cancer. Journal of Gastroenterology and Hepatology, 25(4), 823-831. http://dx.doi.org/10.1111/j.1440-1746.2009.06191.x. PMid:20492341.

Chen, Y., Zhang, Y., Ye, G., Sheng, C., Kong, L., \& Yuan, L. (2020). Knockdown of lncRNA PCAI protects against cognitive decline induced by hippocampal neuroinflammation via regulating SUZ12. Life Sciences, 253, 117626. http://dx.doi.org/10.1016/j.lfs.2020.117626. PMid:32247002.

Cheng, S., Yu, P., Yang, L., Shi, H., He, A., Chen, H., Han, J., Xie, L., Chen, J., \& Chen, X. (2016). Astragaloside IV enhances cardioprotection of remote ischemic conditioning after acute myocardial infarction in rats. American Journal of Translational Research, 8(11), 46574669. PMid:27904669.
Cheng, S., Zhang, X., Feng, Q., Chen, J., Shen, L., Yu, P., Yang, L., Chen, D., Zhang, H., Sun, W., \& Chen, X. (2019). Astragaloside IV exerts angiogenesis and cardioprotection after myocardial infarction via regulating PTEN/PI3K/Akt signaling pathway. Life Sciences, 227, 82-93. http://dx.doi.org/10.1016/j.lfs.2019.04.040. PMid:31004658.

Du, J., Liu, J., Zhen, J., Yang, S. T., Zheng, E. L., \& Leng, J. Y. (2019). Astragaloside IV protects cardiomyocytes from hypoxia-induced injury by down-regulation of IncRNA GAS5. Biomedicine and Pharmacotherapy, 116, 109028. http://dx.doi.org/10.1016/j. biopha.2019.109028. PMid:31136949.

Gong, L., Chang, H., Zhang, J., Guo, G., Shi, J., \& Xu, H. (2018). Astragaloside IV protects rat cardiomyocytes from HypoxiaInduced injury by down-regulation of miR-23a and miR-92a. Cellular Physiology and Biochemistry, 49(6), 2240-2253. http:// dx.doi.org/10.1159/000493827. PMid:30257251.

Hou, J., Wang, C., Ma, D., Chen, Y., Jin, H., An, Y., Jia, J., Huang, L., \& Zhao, H. (2021). The cardioprotective and anxiolytic effects of Chaihujialonggumuli granule on rats with anxiety after acute myocardial infarction is partly mediated by suppression of CXCR4/NF- $\mathrm{kB} /$ GSDMD pathway. Biomedicine and Pharmacotherapy, 133, 111015. http://dx.doi.org/10.1016/j.biopha.2020.111015. PMid:33232924.

Leng, B., Zhang, Y., Liu, X., Zhang, Z., Liu, Y., Wang, H., \& Lu, M. (2019). Astragaloside IV suppresses high glucose-induced NLRP3 inflammasome activation by inhibiting TLR4/NF- $\kappa B$ and CaSR. Mediators of Inflammation, 2019, 1082497. http://dx.doi. org/10.1155/2019/1082497. PMid:30906223.

Li, L., Hou, X., Xu, R., Liu, C., \& Tu, M. (2017a). Research review on the pharmacological effects of astragaloside IV. Fundamental \& Clinical Pharmacology, 31(1), 17-36. http://dx.doi.org/10.1111/ fcp.12232. PMid:27567103.

Li, X., Zhou, J., \& Huang, K. (2017b). Inhibition of the lncRNA Mirt1 attenuates acute myocardial infarction by suppressing NF- $\kappa \mathrm{B}$ activation. Cellular Physiology and Biochemistry, 42(3), 1153-1164. http://dx.doi.org/10.1159/000478870. PMid:28668956.

Liao, J., He, Q., Li, M., Chen, Y., Liu, Y., \& Wang, J. (2016). LncRNA MIAT: myocardial infarction associated and more. Gene, 578(2), 158161. http://dx.doi.org/10.1016/j.gene.2015.12.032. PMid:26707210.

Liu, Y., Wang, T., Zhang, M., Chen, P., \& Yu, Y. (2019). Down-regulation of myocardial infarction associated transcript 1 improves myocardial ischemia-reperfusion injury in aged diabetic rats by inhibition of activation of NF- $\mathrm{kB}$ signaling pathway. Chemico-Biological Interactions, 300, 111-122. http://dx.doi.org/10.1016/j.cbi.2019.01.001. PMid:30611788.

Lotem, J., Levanon, D., Negreanu, V., Bauer, O., Hantisteanu, S., Dicken, J., \& Groner, Y. (2015). Runx3 at the interface of immunity, inflammation and cancer. Biochimica et Biophysica Acta, 1855(2), 131-143. PMid:25641675.

Lotem, J., Levanon, D., Negreanu, V., Bauer, O., Hantisteanu, S., Dicken, J., \& Groner, Y. (2017). Runx3 in immunity, inflammation and cancer. Advances in Experimental Medicine and Biology, 962, 369-393. http://dx.doi.org/10.1007/978-981-10-3233-2_23. PMid:28299669.

Lu, L., Liu, M., Sun, R., Zheng, Y., \& Zhang, P. (2015). Myocardial infarction: symptoms and treatments. Cell Biochemistry and Biophysics, 72(3), 865-867. http://dx.doi.org/10.1007/s12013-0150553-4. PMid:25638347.

Oh, S., Ko, J. Y., Oh, C., \& Yoo, K. H. (2017). Targeting the epigenome as a novel therapeutic approach for breast cancer. Advances in Experimental Medicine and Biology, 1026, 287-313. http://dx.doi. org/10.1007/978-981-10-6020-5_14. PMid:29282690. 
Pollard, T. J. (2000). The acute myocardial infarction. Primary Care, 27(3), 631-649. http://dx.doi.org/10.1016/S0095-4543(05)70167-6. PMid:10918673.

Thoma, A., \& Lightfoot, A. P. (2018). NF-kB and inflammatory cytokine signalling: role in skeletal muscle Atrophy. Advances in Experimental Medicine and Biology, 1088, 267-279. http://dx.doi.org/10.1007/978981-13-1435-3_12. PMid:30390256.

Wang, S. G., Xu, Y., Xie, H., Wang, W., \& Chen, X. H. (2015). Astragaloside IV prevents lipopolysaccharide-induced injury in $\mathrm{H} 9 \mathrm{C} 2$ cardiomyocytes. Chinese Journal of Natural Medicines, 13(2), 127-132. http://dx.doi. org/10.1016/S1875-5364(15)60016-4. PMid:25769895.

Wang, Y., Yang, X., Jiang, A., Wang, W., Li, J., \& Wen, J. (2019). Methylation-dependent transcriptional repression of RUNX3 by KCNQ1OT1 regulates mouse cardiac microvascular endothelial cell viability and inflammatory response following myocardial infarction. The FASEB Journal, 33(12), 13145-13160. http://dx.doi. org/10.1096/fj.201900310R. PMid:31625414.

Whittle, M. C., \& Hingorani, S. R. (2017). Runx3 and cell fate decisions in pancreas cancer. Advances in Experimental Medicine and Biology, 962, 333-352. http://dx.doi.org/10.1007/978-981-10-3233-2_21. PMid:28299667.

Xu, F., Cui, W. Q., Wei, Y., Cui, J., Qiu, J., Hu, L. L., Gong, W. Y., Dong, J. C., \& Liu, B. J. (2018). Astragaloside IV inhibits lung cancer progression and metastasis by modulating macrophage polarization through AMPK signaling. Journal of Experimental \& Clinical Cancer Research, 37(1), 207. http://dx.doi.org/10.1186/s13046-018-0878-0. PMid:30157903.

Yang, J., Huang, X., Hu, F., Fu, X., Jiang, Z., \& Chen, K. (2019). LncRNA ANRIL knockdown relieves myocardial cell apoptosis in acute myocardial infarction by regulating IL-33/ST2. Cell Cycle, 18(23), 3393-3403. http://dx.doi.org/10.1080/15384101.2019.1678965. PMid:31674275.

Yang, X., Wang, S., \& Reheman, A. (2020). Regulation of RUNX3 expression by DNA methylation in prostate cancer. Cancer Management and Research, 12, 6411-6420. http://dx.doi.org/10.2147/CMAR. S249066. PMid:32801881.

Yu, J. M., Zhang, X. B., Jiang, W., Wang, H. D., \& Zhang, Y. N. (2015). Astragalosides promote angiogenesis via vascular endothelial growth factor and basic fibroblast growth factor in a rat model of myocardial infarction. Molecular Medicine Reports, 12(5), 6718-6726. http:// dx.doi.org/10.3892/mmr.2015.4307. PMid:26352430.

Yu, J., Tian, X., Chang, J., Liu, P., \& Zhang, R. (2017). RUNX3 inhibits the proliferation and metastasis of gastric cancer through regulating miR-182/HOXA9. Biomedicine and Pharmacotherapy, 96, 782-791. http://dx.doi.org/10.1016/j.biopha.2017.08.144. PMid:29054094.

Zangrando, J., Zhang, L., Vausort, M., Maskali, F., Marie, P. Y., Wagner, D. R., \& Devaux, Y. (2014). Identification of candidate long non-coding RNAs in response to myocardial infarction. BMC Genomics, 15(1), 460. http://dx.doi.org/10.1186/1471-2164-15-460. PMid:24917243.

Zeymer, U. (2019). Diagnosis and initial management of acute myocardial infarction. MMW Fortschritte der Medizin, 161(4), 34-36. http:// dx.doi.org/10.1007/s15006-019-0223-3. PMid:30830611.

Zhang, J., \& He, J. F. (2020). LncRNA-MALAT1 influences myocardial infarction by regulating miR-30a/beclin-1 pathway. European Review for Medical and Pharmacological Sciences, 24(2), 885-892. PMid:32016995.

Zhang, J., Wu, C., Gao, L., Du, G., \& Qin, X. (2020). Astragaloside IV derived from Astragalus membranaceus: a research review on the pharmacological effects. Advances in Pharmacology, 87, 89-112. http://dx.doi.org/10.1016/bs.apha.2019.08.002. PMid:32089240.

Zheng, Y., Dai, Y., Liu, W., Wang, N., Cai, Y., Wang, S., Zhang, F., Liu, P., Chen, Q., \& Wang, Z. (2019). Astragaloside IV enhances taxol chemosensitivity of breast cancer via caveolin-1-targeting oxidant damage. Journal of Cellular Physiology, 234(4), 4277-4290. http:// dx.doi.org/10.1002/jcp.27196. PMid:30146689.

Zhou, X., Zhu, J., Bian, T., Wang, R., \& Gao, F. (2017). Mislocalization of Runt-related transcription factor 3 results in airway inflammation and airway hyper-responsiveness in a murine asthma model. Experimental and Therapeutic Medicine, 14(3), 2695-2701. http:// dx.doi.org/10.3892/etm.2017.4812. PMid:28962214.

Zuo, J., Xia, J., Ju, F., Yan, J., Zhu, A., Jin, S., Shan, T., \& Zhou, H. (2013). MicroRNA-148a can regulate runt-related transcription factor 3 gene expression via modulation of DNA methyltransferase 1 in gastric cancer. Molecules and Cells, 35(4), 313-319. http://dx.doi. org/10.1007/s10059-013-2314-9. PMid:23549984. 